LA-14234

Approved for public release;

distribution is unlimited.

\title{
Ambient Air Radionuclide Concentrations at and near TA-50 from 2003 through the First Quarter of 2004
}

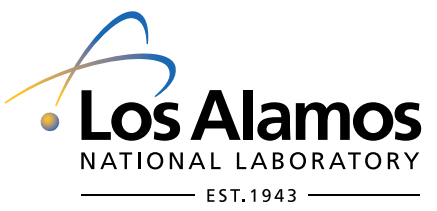

The World's Greatest Science Protecting America 
Los Alamos National Laboratory, an affirmative action/equal opportunity employer, is operated by the University of California for the United States Department of Energy under contract W-7405-ENG-36.

This report was prepared as an account of work sponsored by an agency of the United States Government. Neither the Regents of the University of California, the United States Government nor any agency thereof, nor any of their employees make any warranty, express or implied, or assume any legal liability or responsibility for the accuracy, completeness, or usefulness of any information, apparatus, product, or process disclosed, or represent that its use would not infringe privately owned rights. Reference herein to any specific commercial product, process, or service by trade name, trademark, manufacturer, or otherwise does not necessarily constitute or imply its endorsement, recommendation, or favoring by the Regents of the University of California, the United States Government, or any agency thereof. The views and opinions of authors expressed herein do not necessarily state or reflect those of the Regents of the University of California, the United States Government, or any agency thereof. Los Alamos National Laboratory strongly supports academic freedom and a researcher's right to publish; as an institution, however, the Laboratory does not endorse the viewpoint of a publication or guarantee its technical correctness. 
LA-14234

Issued: September 2005

\section{Ambient Air Radionuclide Concentrations \\ at and near TA-50 from 2003 through \\ the First Quarter of 2004}

Keith W. Jacobson

Craig F. Eberhart 



\title{
AMBIENT AIR RADIONUCLIDE CONCENTRATIONS AT AND NEAR TA-50 FROM 2003 THROUGH THE FIRST QUARTER OF 2004
}

by

\author{
Keith W. Jacobson and Craig F. Eberhart
}

\begin{abstract}
The Meteorology and Air Quality (MAQ) group at Los Alamos National Laboratory maintains and operates a large network of environmental air samplers called AIRNET. Some of these samplers are located near Material Disposal Area C at TA-50, a low-level radioactive waste burial site in the semiarid environment of the Pajarito Plateau, near Los Alamos. AIRNET sampling media consist of a filter and silica gel. They are exchanged once every 2 weeks. Presented are 5 months of air sampling results for 5 stations operating in the vicinity of Material Disposal Area C.
\end{abstract}

\section{Introduction}

The radiological air-sampling network, referred to as AIRNET, at Los Alamos National Laboratory (LANL or the Laboratory) is operated by the Air Quality Monitoring Team in the Meteorology and Air Quality Group (MAQ). AIRNET is designed to measure environmental levels of airborne radionuclides that may be released from Laboratory operations. These emissions include plutonium, americium, uranium, tritium, and activation products. The Laboratory currently operates about 50 environmental air samplers to sample radionuclides by collecting water vapor and particulate matter. This data analysis is a review of particulate matter AIRNET data collected near TA-50 from the beginning of 2003 through the second quarter of 2004 to evaluate radionuclide air concentrations in the vicinity of Materials Disposal Area C. The following sites listed in Table 1 were included in this review and are shown in Figure 1.

\begin{tabular}{cl}
\hline \hline \multicolumn{2}{c}{ Table 1. AIRNET Samplers near TA-50 } \\
\hline \multicolumn{1}{c}{ Site Number } & \multicolumn{1}{c}{ Site Name } \\
\hline $\mathbf{5 3}$ & TA-50, MDA-C sampler \\
$\mathbf{1 2}$ & Royal Crest sampler \\
$\mathbf{2 3}$ & TA-5 sampler \\
$\mathbf{7 7}$ & TA-36, IJ Site sampler \\
$\mathbf{2 6}$ & TA-49 sampler \\
\hline \hline
\end{tabular}




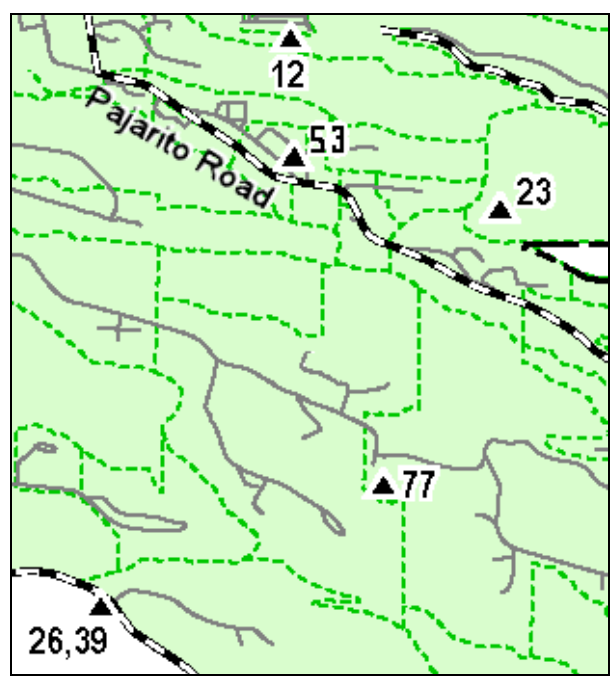

Figure 1. Location of Sampler \#53 and adjacent samplers.

Generally, each AIRNET sampler continuously collects particulate matter for approximately two weeks per sample. Particulate matter is collected on 47-mm polypropylene filters at airflow rates of about $0.11 \mathrm{~m}^{3}$ per minute $(4 \mathrm{cfm})$. Individual particulate matter filters are analyzed for gross alpha and gross beta activities. We also combine half-filters from the six or seven sampling periods at each site during the quarter to prepare a quarterly composite for isotopic analyses for each AIRNET station. These composites are dissolved, separated chemically, and then analyzed for isotopes of americium, plutonium, and uranium using alpha spectroscopy. All analytical procedures meet the requirements of 40 Code of Federal Regulations (CFR) 61, Appendix B, Method 114. The AIRNET project plan provides a summary of the target minimum detectable activity (MDA) for the biweekly and quarterly samples.

All AIRNET concentrations and doses are total measurements without any type of regional background subtractions. The AIRNET air concentrations are blank corrected to include corrections for the radioactivity from the filter material and the analytical process.

The Meteorology and Air Quality Group (MAQ) compares ambient air concentrations, as calculated from the AIRNET sample measurements, with environmental compliance standards or workplace exposure standards, depending on the location of the sampler. For this analysis, annual concentrations are compared with the 10-mrem equivalent concentration established by the Environmental Protection Agency (EPA 1989) and published in 40 CFR, Part 61, Appendix E, Table 2, "Concentration Levels for Environmental Compliance." All radiation doses were calculated by using this $10 \mathrm{mrem}$ concentration as the conversion factor.

\section{Ambient Air Concentrations - alpha and beta}

Figures 2 and 3 present the long-lived gross alpha and beta air concentrations in air at the selected set of samplers. No unusual readings were recorded, except for the first sampling period when the concentrations were somewhat higher. These data were qualified due to some data problems and do not indicate any unexpectedly high concentrations. 


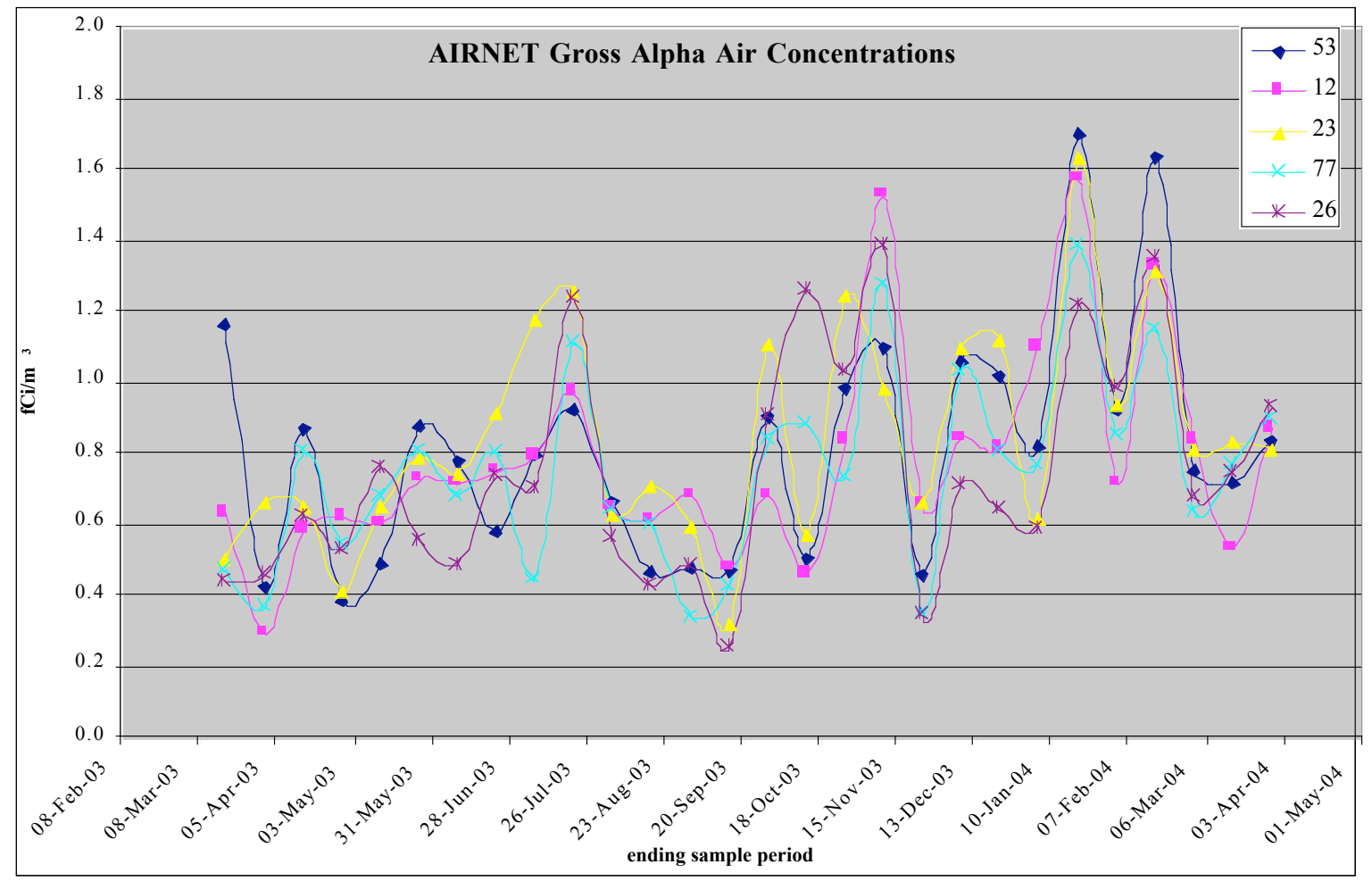

Figure 2

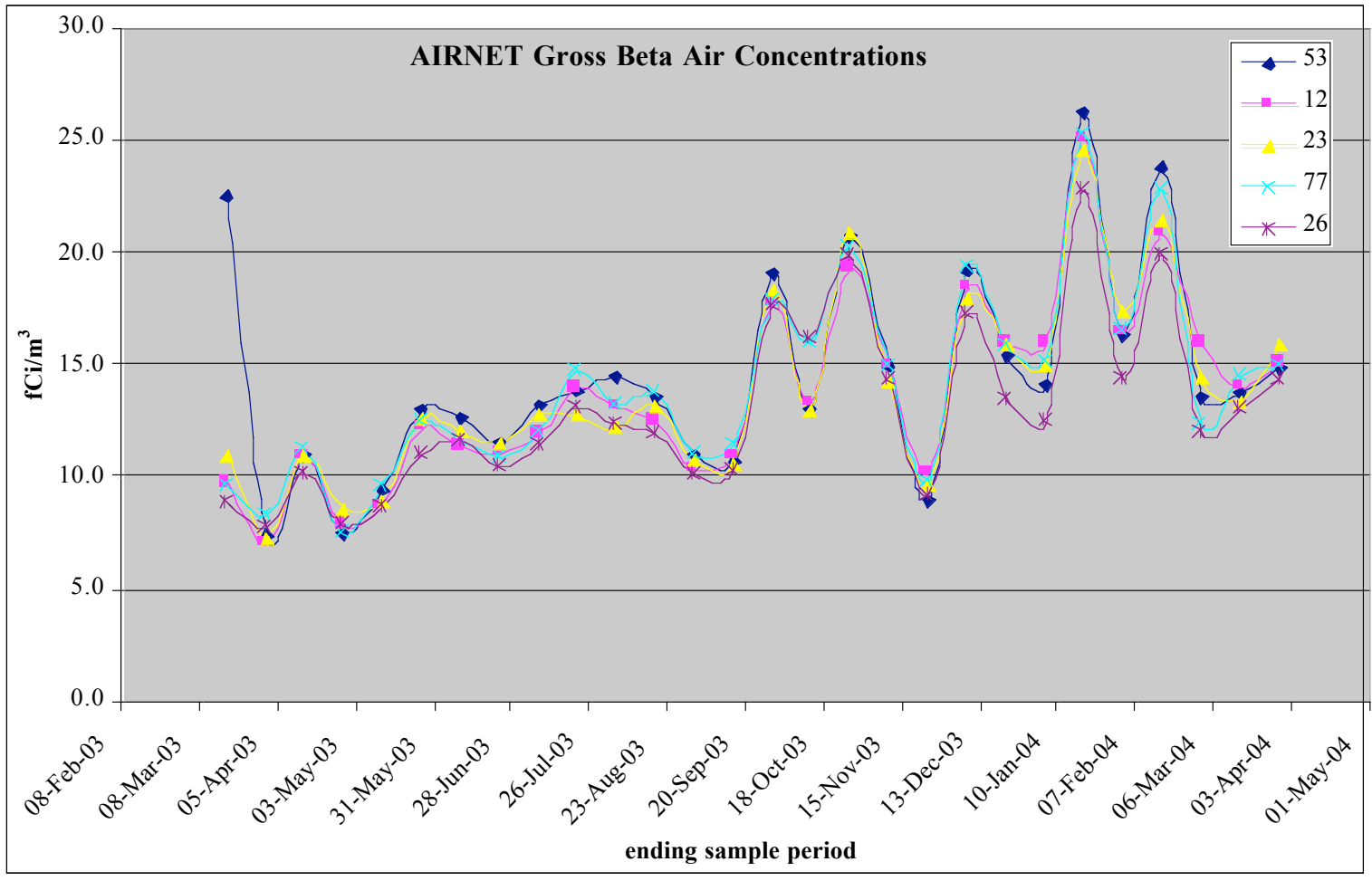

Figure 3 


\section{Ambient Air Concentrations - tritium}

Figure 4 provides airborne tritium results from the TA-50, MDA-C sampler (\#53) and other nearby stations. A series of measurements beginning with the May 26, 2003 sampling period through the Oct. 13, 2003 sample period show tritium results that are above background. A potential source for the elevated readings is tritium vapor escaping from waste buried at Area $\mathrm{C}$. The vapor is driven out of the ground at a greater rate due to increased solar radiation and temperature during the late spring, summer, and early fall. This evapotranspiration-like phenomenon has been observed at our air samplers at MDA-G (Jacobson et al., 2004).

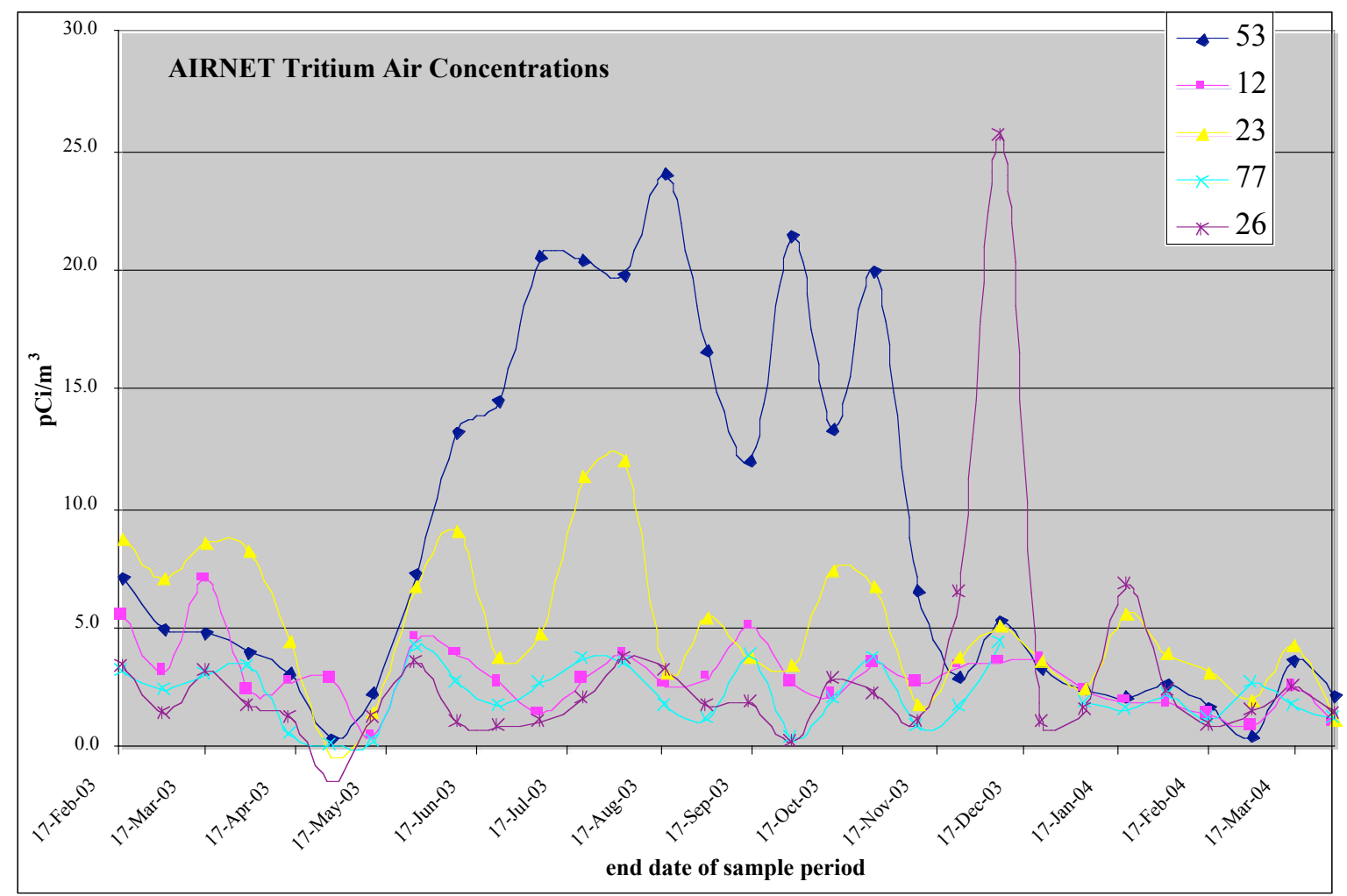

Figure 4

However, there are other nearby sources of tritium emissions that could also be the cause of the above background readings, such as stack emissions from two tritium facilities located at TA-21. We performed a simple air-dispersion analysis of the TA-21 tritium emissions for the periods of the elevated readings and found that there was a probable contribution to the elevated readings at stations \#23 and \#53 (please see Appendix B for this analysis).

Elevated tritium measurements frequently occur at MDA-G. A previous study showed that there is a ground-flux of tritium from certain locations inside MDA-G (Ekland, 1995). We analyzed the possibility these diffuse emissions could have added to the higher readings at samplers \#23 and \#53 and concluded there would not have been an impact. 
We also used air-dispersion modeling to determine that the single high reading at Station \#26 in early December 2003 was due to a small tritium release from TA-16.

\section{Ambient Air Concentrations - selected radioisotopes}

Based on past operating experience with AIRNET, the other radionuclides that could potentially be above background at LANL include Am-241, Pu-238, Pu-239 and depleted uranium. Air concentrations from individual samples are shown in Tables 2 and 3 for these radionuclides and for the three uranium isotopes (U-234, U-235, and U-238).

Radionuclide concentrations are graphically compared between sites in Figures 4, 5, 6, 7, 8 , and 9. Many of these measurements are less than their 2-sigma uncertainties, as shown in the table, but the measurements are estimated concentrations instead of "less than" values. Annual isotopic concentrations were calculated for these results (Table 2).

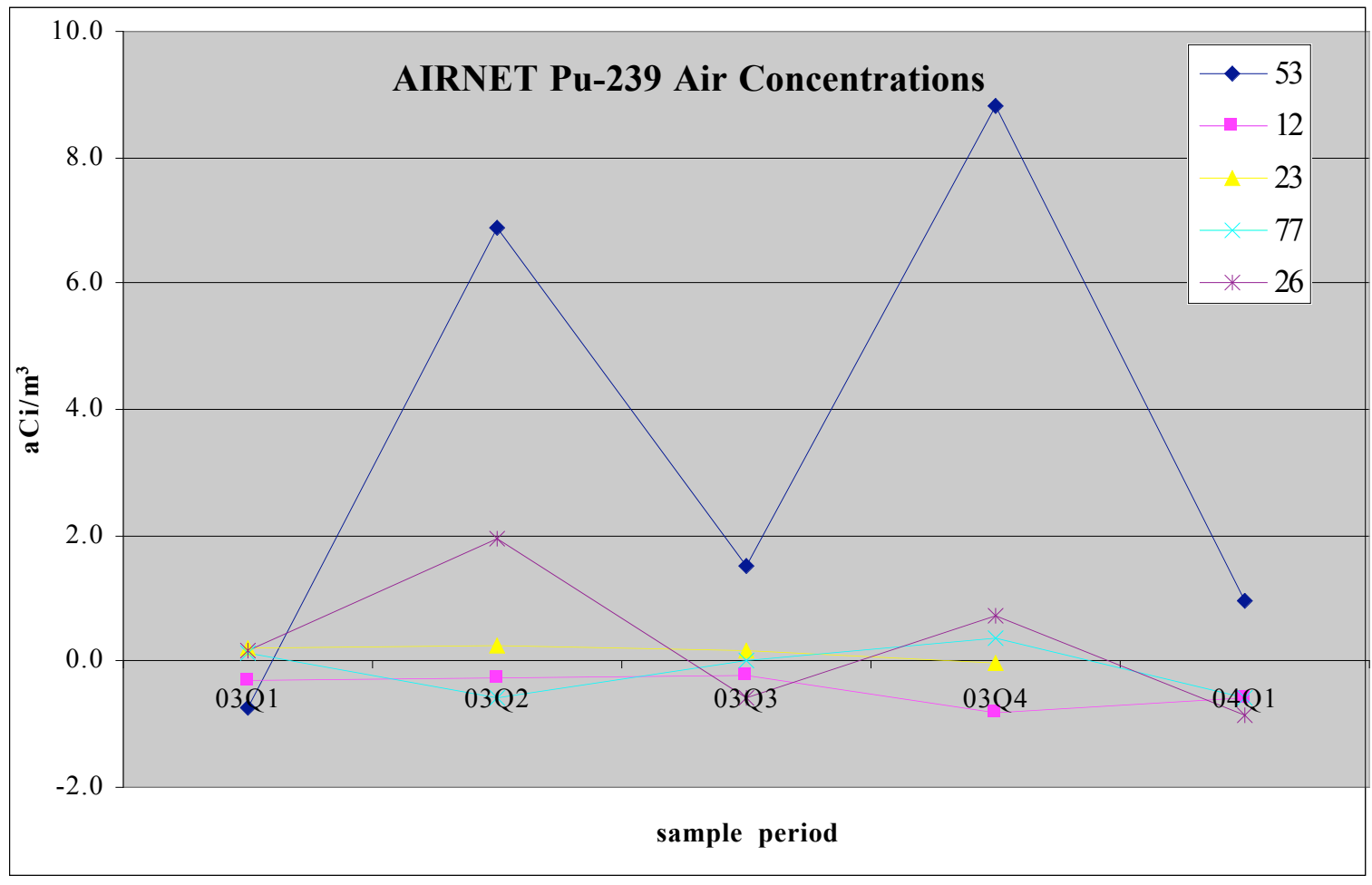

Figure 5 


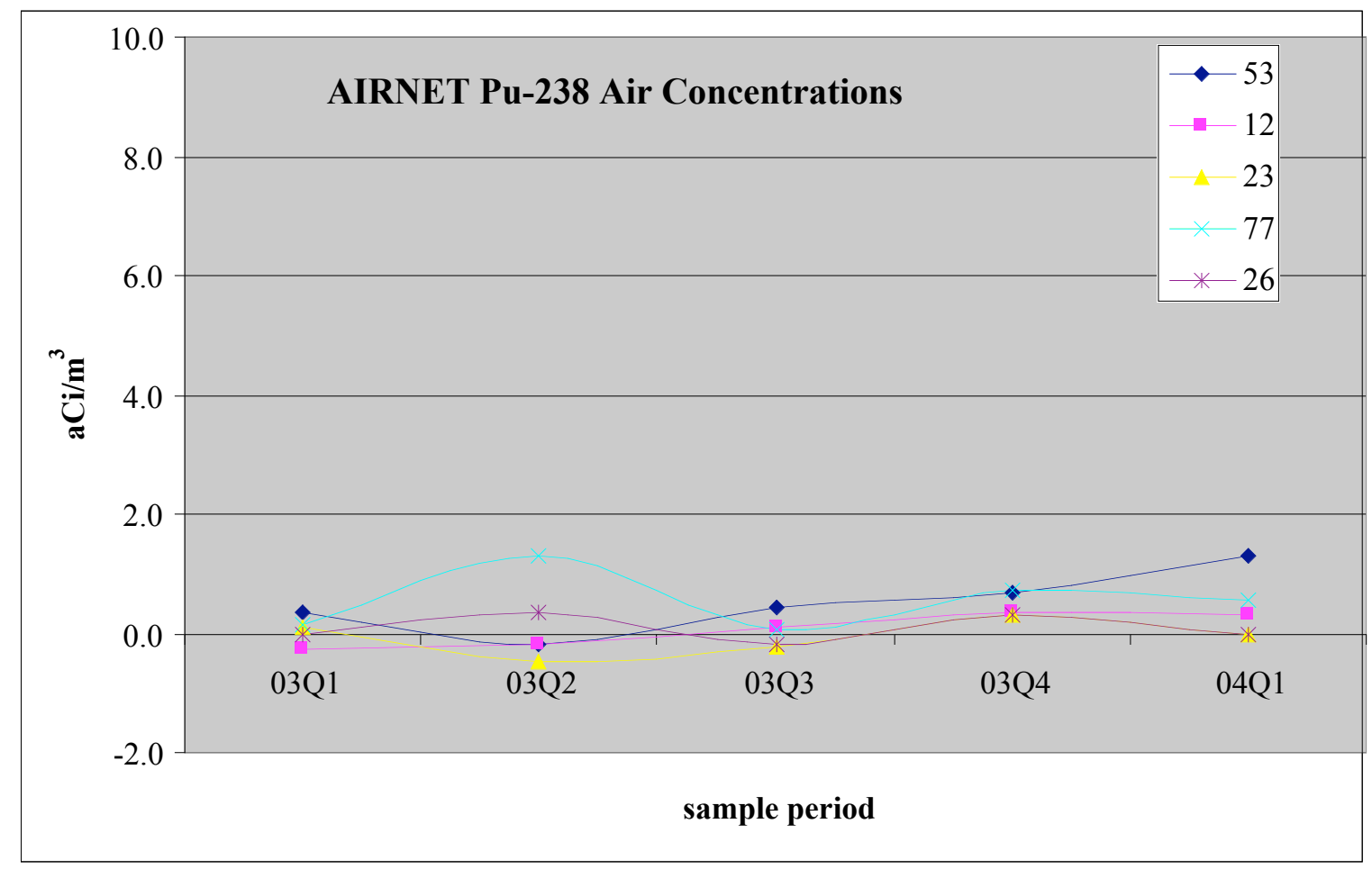

Figure 6

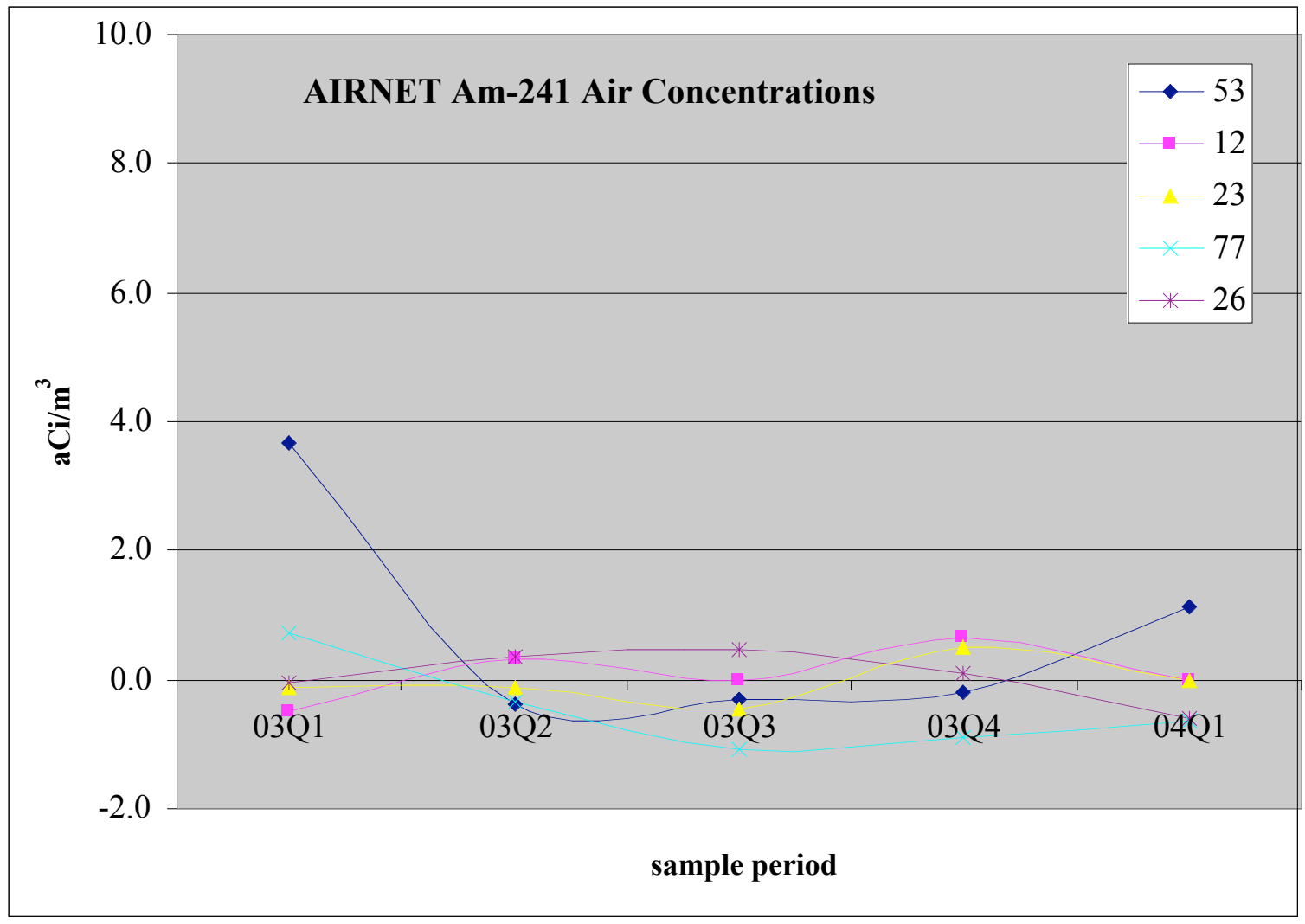

Figure 7 


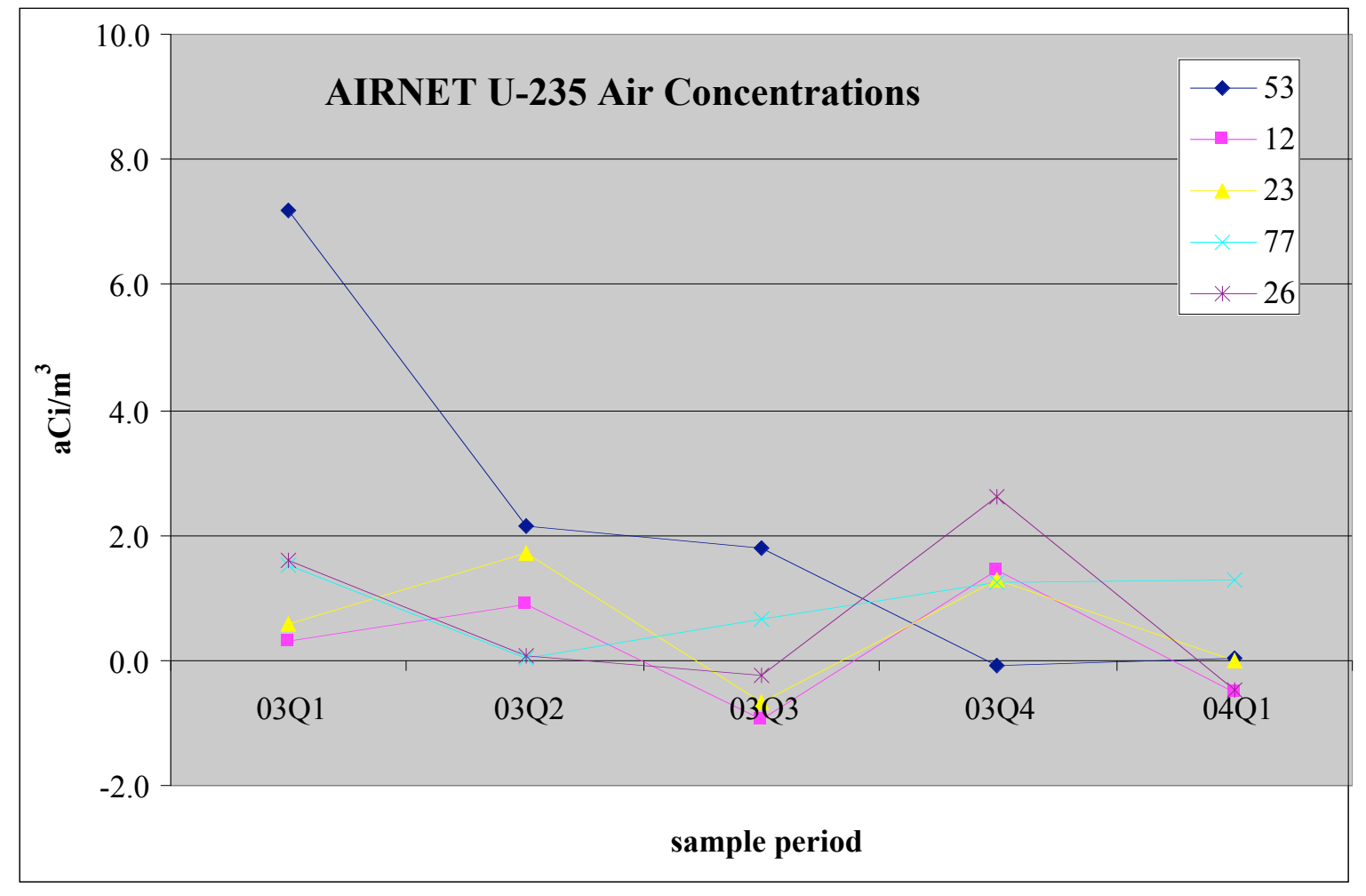

Figure 8

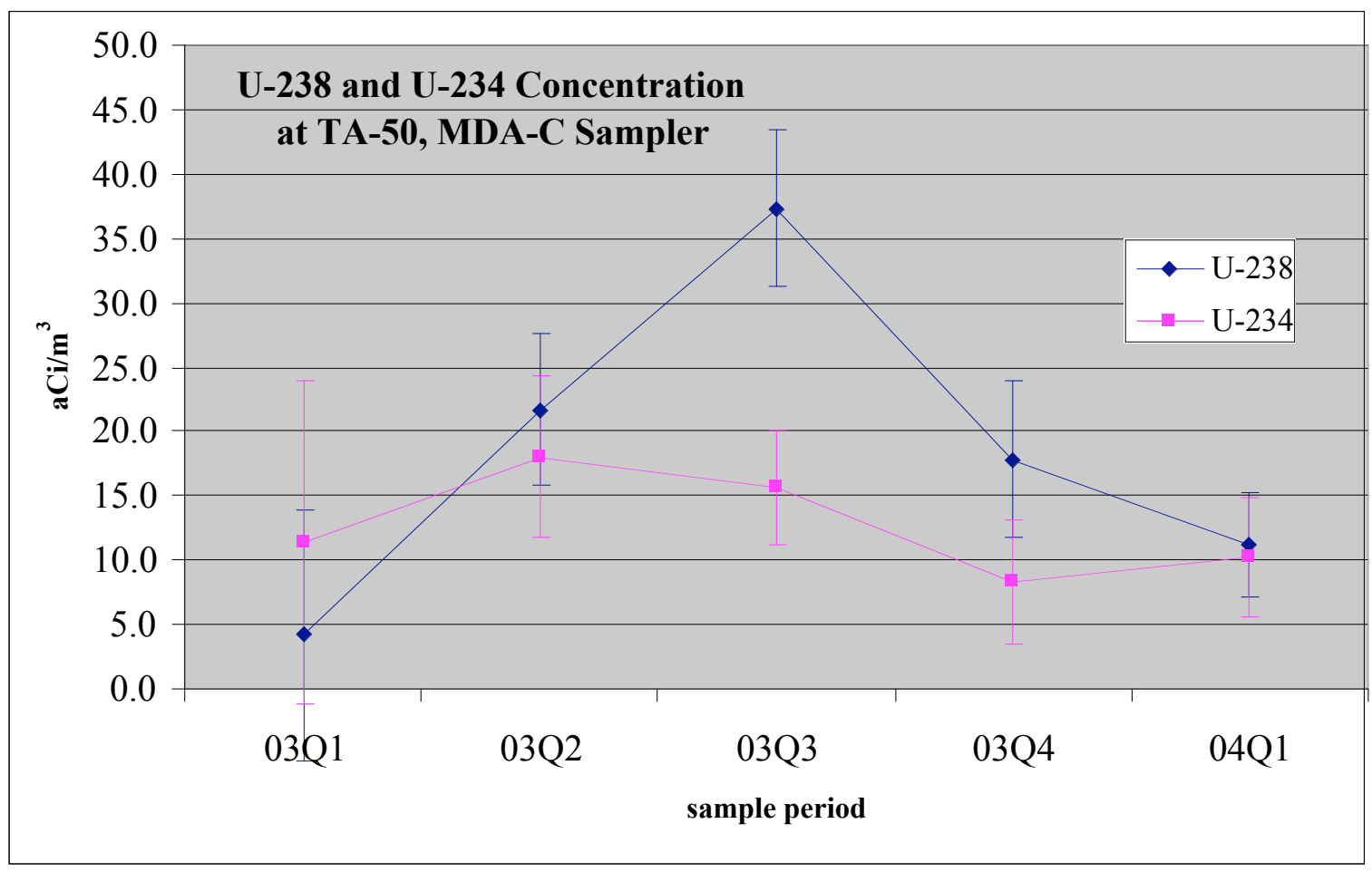

Figure 9 


\begin{tabular}{lcccccc}
\hline \hline \multicolumn{7}{c}{ Table 2. Net Isotopic Readings from Sampler \#53 } \\
\hline
\end{tabular}

\begin{tabular}{|c|c|c|c|c|c|c|}
\hline & \multicolumn{2}{|c|}{$\begin{array}{c}\mathrm{U}-238 \\
\left(\mathrm{aCi} / \mathbf{m}^{3}\right)\end{array}$} & \multicolumn{2}{|c|}{$\begin{array}{c}\mathrm{U}-235 \\
\left(\mathrm{aCi} / \mathrm{m}^{3}\right)\end{array}$} & \multicolumn{2}{|c|}{$\begin{array}{c}\mathrm{U}-234 \\
\left(\mathrm{aCi} / \mathbf{m}^{3}\right)\end{array}$} \\
\hline & Result & $2 s$ & Result & $2 s$ & Result & $2 s$ \\
\hline 03Q1 & 4.2 & 9.8 & 7.2 & 11.4 & 11.4 & 12.5 \\
\hline 03Q2 & 21.7 & 5.9 & 2.1 & 3.1 & 18.0 & 6.3 \\
\hline 03Q3 & 37.3 & 6.1 & 1.8 & 1.9 & 15.6 & 4.4 \\
\hline 03Q4 & 17.8 & 6.1 & -0.1 & 2.7 & 8.3 & 4.9 \\
\hline 04Q1 & 11.2 & 4.1 & 0.0 & 2.0 & 10.2 & 4.6 \\
\hline
\end{tabular}

Two of the Pu-239 readings recorded at sampler \#53 appear to be statistically different than background levels. However, there were no unusual readings of Pu-238, Am-241, or U-235 (Figures 6, 7, 8) that were recorded at any of the sampling stations during this time period.

Uranium concentrations were primarily due to natural uranium from suspended soils, with a few samples showing small amounts of depleted uranium from time to time at LANL. Measurable concentrations of depleted uranium have increased Laboratory-wide since the Cerro Grande fire, but concentrations are still similar to natural levels. For example, as shown in Figure 9, it appears some depleted uranium in air was detected by sampler \#53 during the 3rd quarter of 2003, probably from resuspension of surface contamination at other LANL locations.

\section{Doses and Conclusion}

Figure 10 shows a close-up of the sampler \#53 site in relation to TA-50 and MDA-C. Radiation doses from H-3, Pu-238, Pu-239, Am-241, U-234, U-235, and U-238 were calculated from the annual air concentrations and summed by site as shown in Table 4. Usually about half of these doses are from uranium concentrations that, based on their isotopic signatures, appear to be natural.

Even though detectable concentrations of DU, Pu-239 and tritium were measured, the maximum estimated dose was about 0.1 mrem which is well below the EPA standard of 
10 mrem for DOE facilities. We also calculated a hypothetical dose to a field worker based on the maximum two-week tritium in-air concentration of about $25 \mathrm{pCi} / \mathrm{m}^{3}$. Assuming an 8 -hour work day over a 2 -week work period (10 days) that dose came out to $2 \times 10^{-4} \mathrm{mrem}$.

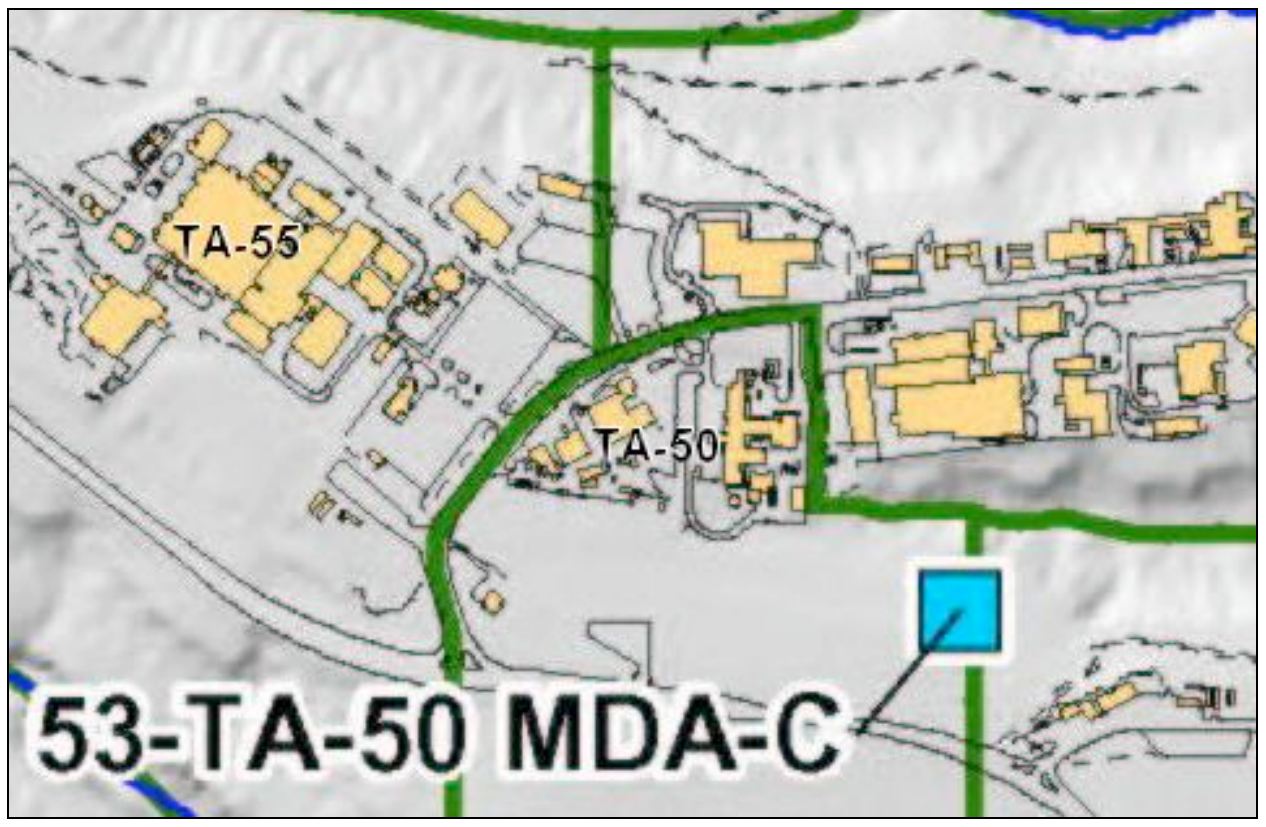

Figure 10. Close-up view of location of sampler \#53 TA-50, MDA-C.

\begin{tabular}{|c|c|c|c|}
\hline Radioisotope & $\begin{array}{c}\text { Dose } \\
\text { Factor } \\
\left(\mathrm{yr} \mathrm{m}^{3} / \mathrm{mrem} \mathrm{pCi}\right) \\
\end{array}$ & $\begin{array}{c}\text { Average } \\
\text { Concentration } \\
\left(\mathrm{pCi} / \mathrm{m}^{3}\right) \\
\end{array}$ & $\begin{array}{c}\text { Estimated } \\
\text { Dose } \\
\text { (mrem/yr) } \\
\end{array}$ \\
\hline $\mathrm{H}-3$ & $\begin{array}{c}150 \\
\left(\mathrm{yr} \mathrm{m}^{3} / \mathrm{mrem} \mathrm{aCi}\right) \\
\end{array}$ & $\begin{array}{r}8.8 \\
\left(\mathrm{aCi} / \mathrm{m}^{3}\right) \\
\end{array}$ & $\begin{array}{c}0.059 \\
(\mathrm{mrem} / \mathrm{yr}) \\
\end{array}$ \\
\hline Am-241 & 190 & 0.8 & 0.004 \\
\hline $\mathrm{Pu}-238$ & 210 & 0.5 & 0.002 \\
\hline $\mathrm{Pu}-239$ & 200 & 3.5 & 0.017 \\
\hline U-234 & 770 & 12.7 & 0.016 \\
\hline U-235 & 710 & 2.2 & 0.003 \\
\hline \multirow[t]{2}{*}{$\mathrm{U}-238$} & 830 & 18.4 & 0.022 \\
\hline & & Sum $=$ & 0.125 \\
\hline
\end{tabular}




\section{References}

Keith W. Jacobson and Craig F. Eberhart, "Air-Sampling from Area G: A RadioactiveWaste Management Site,” Los Alamos National Laboratory report LA-14090 (2004).

Bart Eklund, "Measurements of Emission Fluxes from Technical Area 53, Areas G and L," Radian Corporation report, Austin, Texas (1995). 


\section{Appendix A. Tritium Results for Station \#53}

\begin{tabular}{|c|c|c|c|c|}
\hline $\begin{array}{c}\text { Sample } \\
\text { Period } \\
\text { ID }\end{array}$ & $\begin{array}{l}\text { Start } \\
\text { Date }\end{array}$ & $\begin{array}{c}\text { Ending } \\
\text { Date }\end{array}$ & $\begin{array}{c}\text { Net Tritium } \\
\text { Air } \\
\text { Concentration } \\
\left(\mathbf{p C i} / \mathbf{m}^{3}\right)\end{array}$ & $\begin{array}{c}\text { 2-sigma } \\
\text { Uncertainty } \\
\left(\mathbf{p C i} / \mathbf{m}^{3}\right)\end{array}$ \\
\hline 030217 & $02 / 03 / 2003$ & $02 / 17 / 2003$ & 7.2 & 2.5 \\
\hline 030303 & $02 / 17 / 2003$ & $03 / 03 / 2003$ & 5.0 & 1.9 \\
\hline 030317 & 03/03/2003 & $03 / 17 / 2003$ & 4.8 & 1.8 \\
\hline 030331 & $03 / 17 / 2003$ & $03 / 31 / 2003$ & 4.0 & 1.9 \\
\hline 030414 & $03 / 31 / 2003$ & $04 / 14 / 2003$ & 3.1 & 1.9 \\
\hline 030428 & $04 / 14 / 2003$ & $04 / 28 / 2003$ & 0.4 & 2.4 \\
\hline 030512 & $04 / 28 / 2003$ & $05 / 12 / 2003$ & 2.3 & 1.6 \\
\hline 030526 & $05 / 12 / 2003$ & $05 / 26 / 2003$ & 7.3 & 2.7 \\
\hline 030609 & $05 / 26 / 2003$ & 06/09/2003 & 13.2 & 4.4 \\
\hline 030623 & $06 / 09 / 2003$ & $06 / 23 / 2003$ & 14.6 & 3.7 \\
\hline 030707 & $06 / 23 / 2003$ & $07 / 07 / 2003$ & 20.6 & 4.3 \\
\hline 030721 & $07 / 07 / 2003$ & $07 / 21 / 2003$ & 20.5 & 4.5 \\
\hline 030804 & $07 / 21 / 2003$ & $08 / 04 / 2003$ & 19.8 & 4.9 \\
\hline 030818 & $08 / 04 / 2003$ & $08 / 18 / 2003$ & 24.0 & 6.3 \\
\hline 030901 & $08 / 18 / 2003$ & $09 / 01 / 2003$ & 16.7 & 5.7 \\
\hline 030915 & 09/01/2003 & $09 / 15 / 2003$ & 12.0 & 3.7 \\
\hline 030929 & $09 / 15 / 2003$ & 09/29/2003 & 21.5 & 4.1 \\
\hline 031013 & 09/29/2003 & $10 / 13 / 2003$ & 13.3 & 3.2 \\
\hline 031027 & $10 / 13 / 2003$ & $10 / 27 / 2003$ & 20.0 & 2.9 \\
\hline 031110 & $10 / 27 / 2003$ & $11 / 10 / 2003$ & 6.6 & 2.1 \\
\hline 031124 & $11 / 10 / 2003$ & $11 / 24 / 2003$ & 3.0 & 1.5 \\
\hline 031208 & $11 / 24 / 2003$ & $12 / 08 / 2003$ & 5.4 & 1.5 \\
\hline 031222 & $12 / 08 / 2003$ & $12 / 22 / 2003$ & 3.4 & 1.3 \\
\hline 040105 & $12 / 22 / 2003$ & $01 / 05 / 2004$ & 2.5 & 1.1 \\
\hline 040119 & $01 / 05 / 2004$ & $01 / 19 / 2004$ & 2.2 & 1.2 \\
\hline 040202 & $01 / 19 / 2004$ & $02 / 02 / 2004$ & 2.7 & 1.3 \\
\hline 040216 & $02 / 02 / 2004$ & $02 / 16 / 2004$ & 1.7 & 1.0 \\
\hline 040301 & $02 / 16 / 2004$ & 03/01/2004 & 0.5 & 1.2 \\
\hline 040315 & $03 / 01 / 2004$ & $03 / 15 / 2004$ & 3.7 & 1.4 \\
\hline 040329 & $03 / 15 / 2004$ & $03 / 29 / 2004$ & 2.2 & 1.4 \\
\hline
\end{tabular}




\section{Appendix B. Tritium Air-Dispersion Analysis}

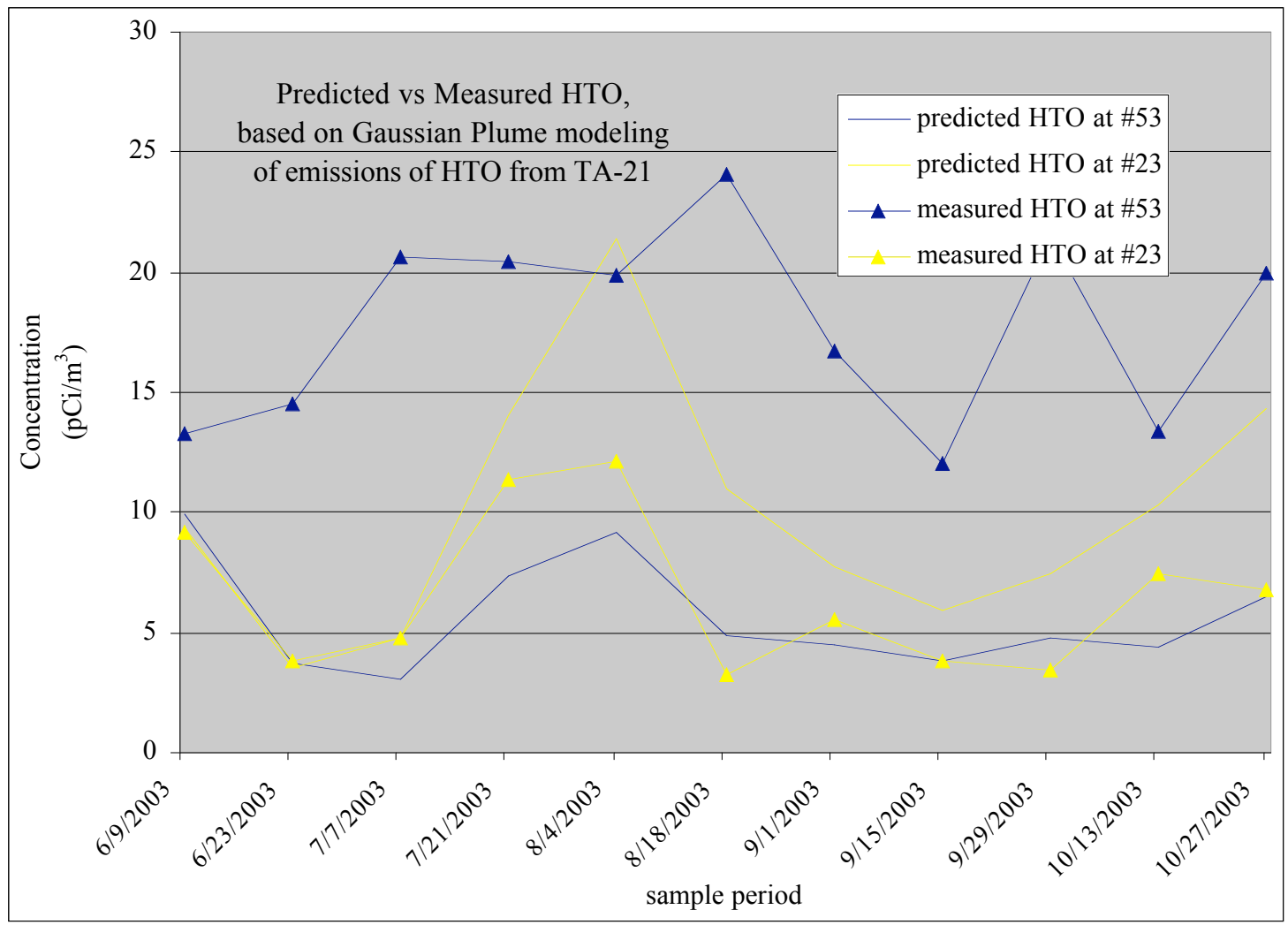

\begin{tabular}{lcc}
\hline \hline \multicolumn{3}{c}{ Bi-Weekly Tritium Emissions } \\
\hline \multicolumn{1}{c}{ Ending } & TA-21-155 & TA-21-209 \\
Date & (\#Ci) & (\#Ci) \\
\hline 9-Jun-2003 & 9.2 & 28.7 \\
23-Jun-2003 & 8.9 & 27.8 \\
7-Jul-2003 & 9.6 & 43.3 \\
21-Jul-2003 & 10.7 & 59.3 \\
4-Aug-2003 & 12.8 & 31.9 \\
18-Aug-2003 & 12.8 & 22.1 \\
1-Sep-2003 & 14.0 & 7.9 \\
15-Sep-2003 & 17.6 & 7.0 \\
29-Sep-2003 & 20.8 & 10.3 \\
13-Oct-2003 & 14.0 & 13.4 \\
27-Oct-2003 & 14.7 & 11.3 \\
\hline \hline
\end{tabular}


This report has been reproduced directly from the best available copy. It is available electronically on the Web (http://www.doe.gov/bridge).

Copies are available for sale to U.S. Department of Energy employees and contractors from:

Office of Scientific and Technical Information P.O. Box 62

Oak Ridge, TN 37831

(865) 576-8401

Copies are available for sale to the public from: National Technical Information Service

U.S. Department of Commerce

5285 Port Royal Road

Springfield, VA 22161

(800) 553-6847 
Los Alamos NATIONAL LABORATORY EST. 1943 